University of Nebraska - Lincoln

DigitalCommons@University of Nebraska - Lincoln

Waterfowl Management Handbook

US Fish \& Wildlife Service

January 1991

\title{
13.1.3. Life History Strategies and Habitat Needs of the Northern Pintail
}

\author{
Leigh H. Fredrickson \\ Gaylord Memorial Laboratory, The School of Natural Resources, University of Missouri-Columbia, Puxico, \\ MO
}

Mickey E. Heitmeyer

Ducks Unlimited

Follow this and additional works at: https://digitalcommons.unl.edu/icwdmwfm

Part of the Environmental Sciences Commons

Fredrickson, Leigh H. and Heitmeyer, Mickey E., "13.1.3. Life History Strategies and Habitat Needs of the Northern Pintail" (1991). Waterfowl Management Handbook. 37.

https://digitalcommons.unl.edu/icwdmwfm/37

This Article is brought to you for free and open access by the US Fish \& Wildlife Service at DigitalCommons@University of Nebraska - Lincoln. It has been accepted for inclusion in Waterfowl Management Handbook by an authorized administrator of DigitalCommons@University of Nebraska - Lincoln. 


\subsubsection{Life History Strategies and Habitat Needs of the Northern Pintail}

Leigh $\mathrm{H}$. F redrickson

Gaylord Memorial Laboratory

The School of Natural Resources

University of Missouri-Col umbia

Puxico, MO 63960

and

Mickey E. Heitmeyer

Ducks Unlimited

9823 Old Winery Place, Suite 16

Sacramento, CA 95827

The northern pintail (hereafter pintail) is a common dabbling duck distributed throughout the Northern Hemisphere. Since 1955, the breeding population in North America has averaged $5,566,000$, fluctuating between 10,124,000 (1956) and 2,471,000 (1989; Fig. 1). Pintail numbers are especially sensitive to habitat conditions that reflect the wet-dry cycle in the shortgrass prairie breeding areas of south-central Canada and the northern Great Plains of the U nited States. Populations of pintails also are affected by habitat conditions in key wintering areas, such as the Central Valley of California and Gulf Coast marshes. When wintering areas are fairly dry, birds have fewer resources and subsequent spring recruitment is lowered.

Through the 1970's, continental populations recovered when wetland conditions on breeding and wintering areas were good but fell when the prairies were dry and wetland conditions in wintering areas were poor. Unfortunately, habitat

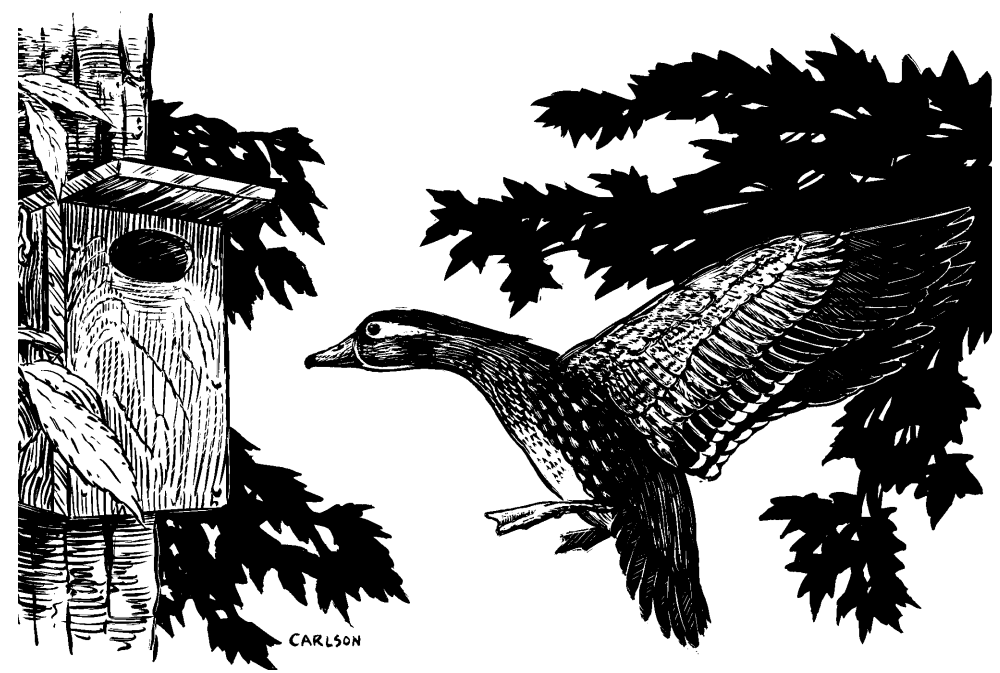

Species Profile-Northern Pintail

Scientific name: Anas acuta

Weight in pounds (grams):

Adults-male $2.3(1,040 \mathrm{~g})$, female $1.9(860 \mathrm{~g})$

I mmatures-male 2 (910 g), female $1.8(820 \mathrm{~g})$

Age of first breeding: 1 year

Clutch size: 8 , range $3-14$

Incubation period: $22-23$ days

Age at fledging: 36-43 days in Alaska,

42-57 days on prairies

Nest sites: L ow, sparse vegetation, often far from water

Food habits: Omnivore; primarily moist-soil seeds, as well as chufa nutlets; cultivated grains, especially rice and barley. Animal foods: aquatic insects, especially chironomids, snails, terrestrial earthworms, and spiders.

losses and degradation of prairie habitats caused by agricultural practices have coincided with prolonged drought since the early 1980's. This combination of detrimental factors resulted in dedining pintail numbers in the past decade. The long-term downward trend in pintail numbers has focused renewed attention on this species.

This leaflet describes aspects of pintail life history that may be important for pintail management. It is not intended as a general reference on pintail biology. Readers interested in this should consult Bell rose (1980). 


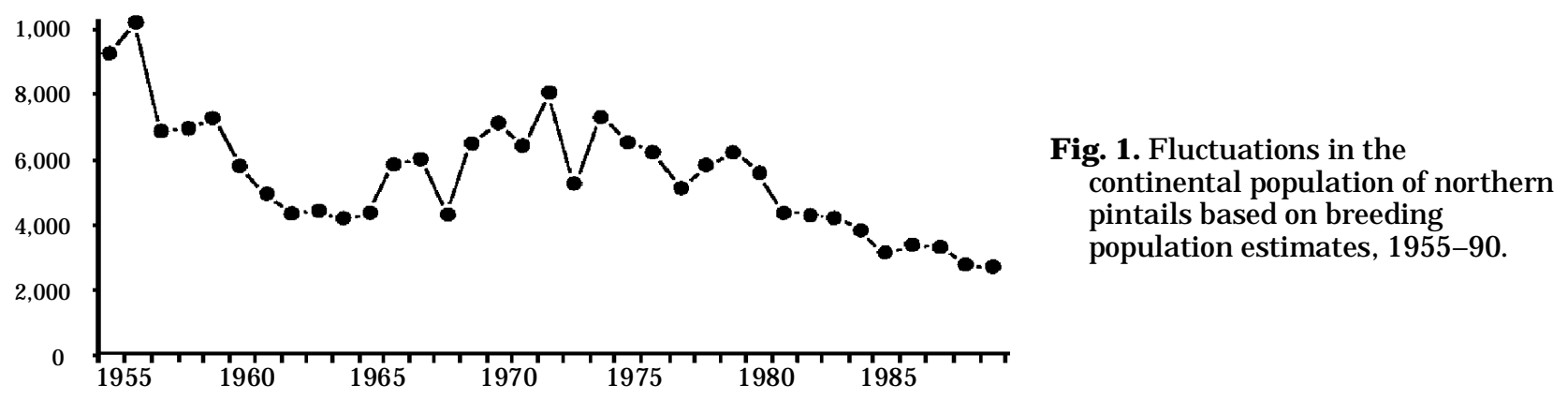

\section{Distribution}

The northern pintail is the most widely distributed dabbling duck in the N orthern Hemisphere. Although pintails regularly breed in the shortgrass prairies of the northern United States and southern Canada, their breeding distribution in North America extends from the
Great Basin into the northern boreal forest and the arctic coastal plain of Alaska and Canada (Fig. 2).

In recent years, about $16 \%$ of the continental population of pintails (counted in May) occurred on the 26,000 square miles of high-latitude wetlands along the arctic coastal plain in Alaska. Pintails compose $90 \%$ of the dabbling ducks that use these habitats; thus, they are the most abundant dabbling duck in this region. Drakes account for about $32 \%$ of this total, whereas pairs account for

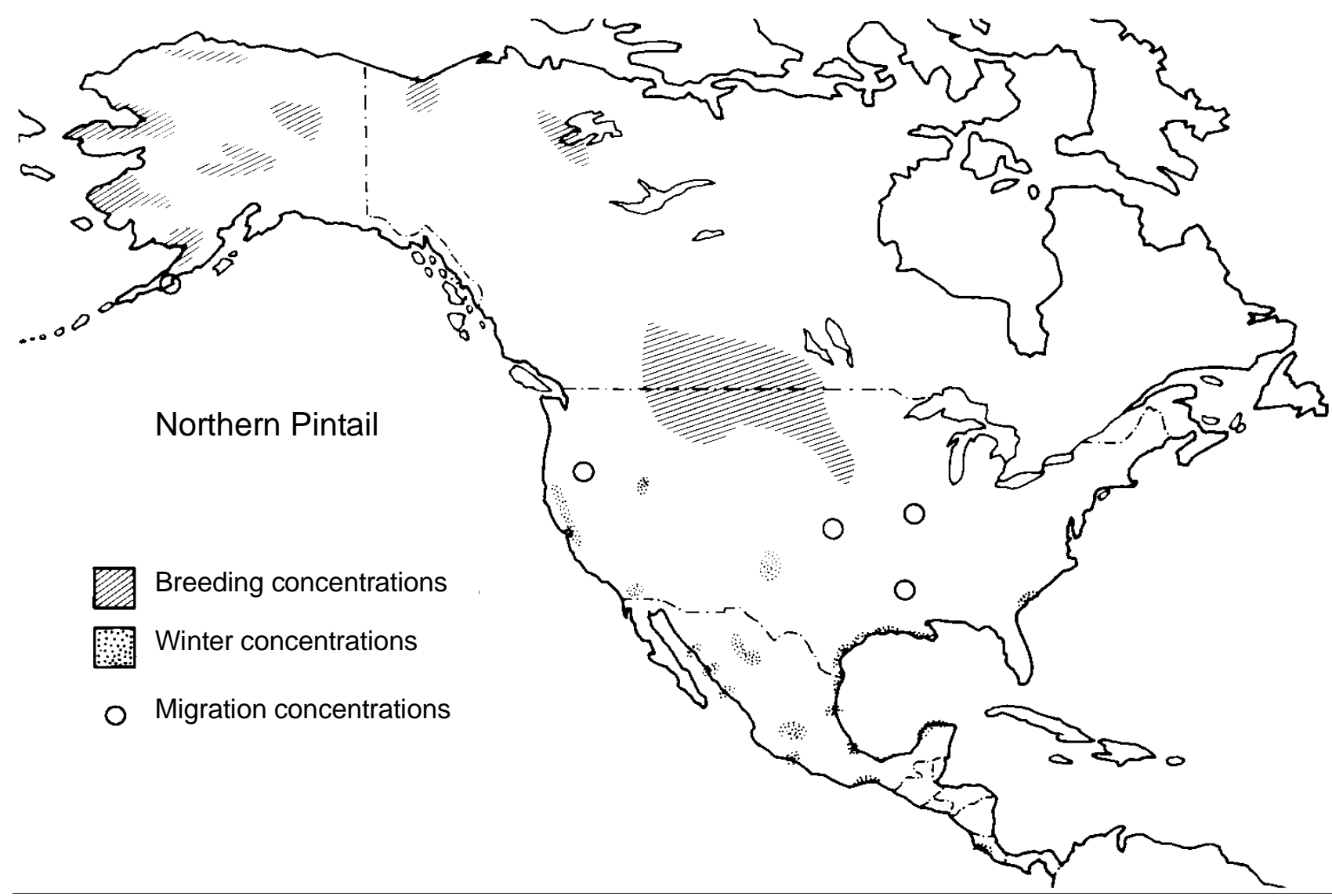

Fig. 2. Distribution of important breeding, wintering, and migration areas for northern pintails. 
$12 \%$ and groups about $57 \%$. Pintails are well known for overflight into more northern wetland habitats when wetland habitat conditions on more southern habitats are poor; therefore, their numbers fluctuate erratically in Alaska.

Most pintails in the Pacific Flyway have traditionally wintered from the Central Valley of California to the west coast of Mexico, but the river deltas of the Pacific Northwest also provide important habitats. Large numbers of pintails also winter in coastal marshes and rice belt habitats in Texas, L ouisiana, Arkansas, and the Atlantic Coast, especially South Carolina.

\section{Spring Migration and Breeding}

Pintails migrate early in spring and move northward as soon as wetlands become ice-free. They normally initiate nesting earlier in spring and summer than other dabblers (Fig. 3). These early-nesting females often encounter light snowfall while laying and incubating. Open habitats with sparse, low vegetation provide favored nesting sites. The shortgrass habitats of the Canadian prairie provinces have traditionally held the highest breeding populations. In the northern United States and southern Canada, first nests appear in early April during normal years, but inclement weather can delay nesting until the second week of May. Nesting activity in the more northern prairies peaks during the first 2 weeks of May. Pintails nest later in the boreal forest; the peak of first nests in Alaska's interior occurs during mid-May. Birds moving to tundra habitats on the Yukon-Kuskokwim Del ta and the North Slope do not nest until late May or as late as mid-J une.

Pintails lay an average clutch of 8 eggs, but clutch size ranges from 3 to 14 . I ncubation lasts 22 or 23 days. Pintail broods can move long distances between the nest site and rearing habitats or among different brood habitats. Recent studies suggest that pintails are well adapted to making these movements and that neither mortality nor

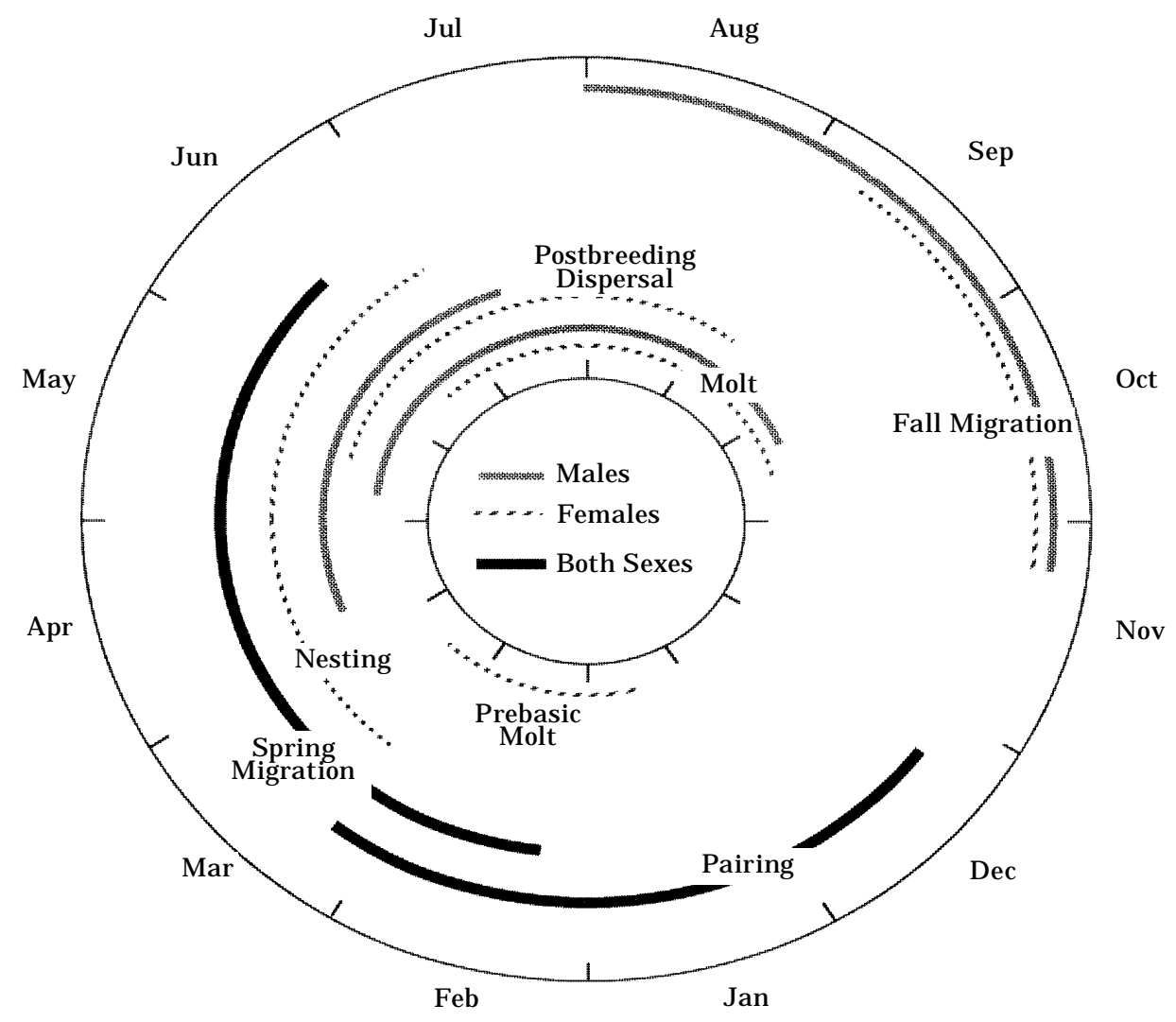

Fig. 3. The chronology of important life history events in the annual cycle of the northern pintail. 
body condition of ducklings is greatly influenced by movements of less than 3 miles. Fledging time varies with latitude and is undoubtedly influenced by the length of daylight and the daily time available to forage. Females stay with the brood until the young reach flight stage. Soon after, the female initiates the summer molt and becomes flightless (Fig. 3).

\section{Postbreeding Dispersal and Fall Migration}

Males congregate in postbreeding flocks once females begin incubation ( $\mathrm{Fig}$. 3). Males may move to southern or northern habitats, where they often form large aggregations and begin the Prebasic molt, becoming flightless for about 3 weeks. After regaining flight in August, they often migrate south to the ultimate wintering areas. For some pintails, the fall migration is a more gradual shift south that extends over several months. Early migrant males begin to move southward in abundance in late August or early September and usually concentrate on seasonally flooded wetlands, where they select seeds from native vegetation or from agricultural crops, especially rice.

Following brood rearing, successful females form small flocks, enter the molt, become flightless, and regrow their flight feathers in rapid succession (Fig. 3). Because males generally leave the breeding area before females are flightless, the latter use habitats distinctly different than those used by males for several months. During this time, females remain on more northern habitats and feed in semi permanent marshes, where invertebrates are important in their diet (Fig. 4). Females gradually join males on migratory and winter sites in October and November. As fall progresses, the two sexes gradually intermix and pair formation begins.

\section{Winter Behavior and Pairing}

Pintails are highly social and have loosely formed pair bonds compared to mallards and most other Northern Hemisphere dabblers. Pair formation by pintails begins on the wintering

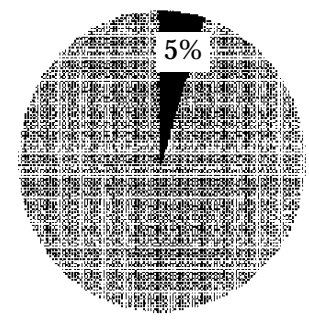

Fall Migration

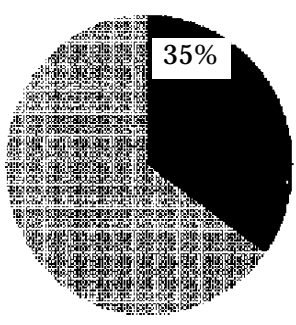

Spring Migration

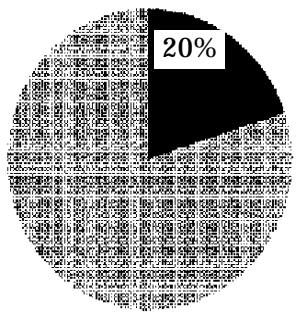

Winter Unpaired

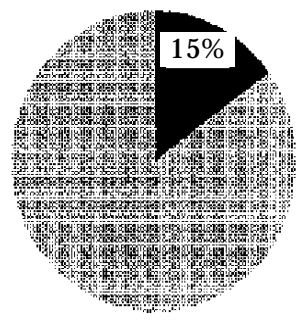

Winter Paired

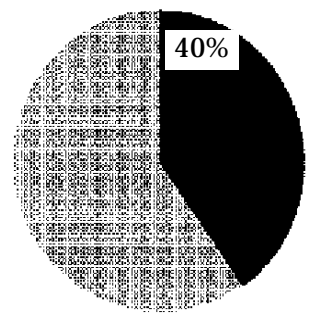

Female Prebasic (Winter)

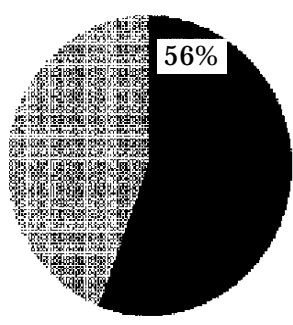

Prelaying

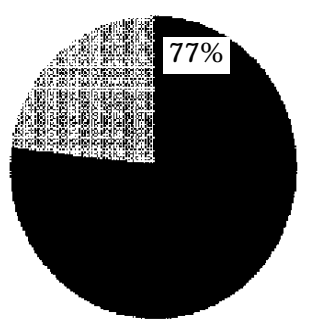

Laying

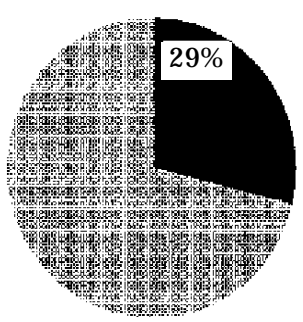

Postlaying

Nesting Females

Fig. 4. I nvertebrate consumption by northern pintails during sel ected events in theannual cyde. Includes both sexes unless indicated otherwise. 
grounds, and most females are paired by J anuary. Courtship flights often contain large numbers of males and traverse great distances, reach great heights, and last for extended periods. On the breeding grounds, these spectacular flights were once bel ieved to distribute the nesting pairs widely among available habitats, but recent studies have not al ways confirmed this assumption-instead, they suggest active competition in mate selection and breeding opportunities among males in spring.

During winter, pintails undergo several important events in the annual cycle (Fig. 3). After completing the Prealternate molt, they form pairs; then, femal es initiate the Prebasic molt. By late winter and early spring, both sexes have accumulated large body fat reserves subsequently used in migration and for breeding. Females departing from the Central Valley of California to Tule Lake in late winter reach weights of $950 \mathrm{~g}$, and of this total, $220 \mathrm{~g}$ is fat necessary to fuel migration and eventual reproduction.

Pintails are early migrants in spring and are especially attracted to large expanses of shallow open water where visibility is good and small seeds and invertebrates are readily available. Their preferred prairie nesting areas are short grasses where temporary ponds are abundant nearby.
Nesting habitat requirements in boreal forest and tundra habitats are less well known.

\section{Foraging E cology}

Pintails are opportunistic omnivores. They primarily consume small seeds, but underground plant parts or small tubers, such as chufa nutlets, also are important (Table 1). If available, native foods are predominant in the diet, especially those associated with moist-soil habitats, including millet, smartweed, bul rush, toothcup, panicum, and swamp timothy. Pintails al so exploit seeds and tubers of aquatic pondweeds and bulrushes. Although they consume seeds of all sizes, they are particularly adept at harvesting smaller seeds such as toothcup, panicum, swamp timothy, and sprangletop. These native foods provide a well-balanced diet to meet nutritional needs (Table 2). Favored cereal grains include rice and barley; pintails are less likely to eat corn than are mallards.

Animal foods are important throughout the life cycle but particularly so during molt and egg laying (Fig. 4). Some of the more important invertebrates

Table 1. Foods appearing in northern pintail diets during different events in the annual cyde

\begin{tabular}{|c|c|c|c|c|c|c|c|c|c|}
\hline Food & $\begin{array}{c}\text { Fall } \\
\text { migration }\end{array}$ & $\frac{\text { Win }}{\text { Unpaired }}$ & $\begin{array}{l}\text { ter } \\
\text { Paired }\end{array}$ & $\begin{array}{c}\text { Prebasic } \\
\text { molt }\end{array}$ & $\begin{array}{l}\text { Spring } \\
\text { migration }\end{array}$ & Nesting & Ducklings & $\begin{array}{c}\text { Summer } \\
\text { molt }\end{array}$ & $\begin{array}{c}\text { Fall } \\
\text { staging }\end{array}$ \\
\hline \multicolumn{10}{|l|}{ Plant } \\
\hline Millet & + & + & + & + & + & + & & & + \\
\hline Swamp timothy & + & + & + & + & & & & & \\
\hline Smartweed & + & + & + & + & + & + & & & + \\
\hline Sprangletop & + & + & + & + & + & & + & + & \\
\hline Toothcup & + & + & + & + & + & + & & & \\
\hline Curly dock & + & & & & + & + & & & \\
\hline Panicum & + & + & + & + & + & + & + & & + \\
\hline Bulrush & + & + & + & + & + & + & & + & + \\
\hline Chufa & + & + & + & + & & & & & \\
\hline Pondweeds & + & & & & + & + & + & + & + \\
\hline Sedges & + & & & & ++ & + & + & + & + \\
\hline $\begin{array}{l}\text { Agricultural } \\
\text { grains }\end{array}$ & + & ++ & + & + & + & & & & + \\
\hline \multicolumn{10}{|l|}{ Animal } \\
\hline Chironomids & + & ++ & + & + & ++ & ++ & + & + & + \\
\hline Snails & & & H & + & + & H & + & H & + \\
\hline Odonates & & & + & + & & & & & \\
\hline Ostracods & & & & + & & & & & \\
\hline
\end{tabular}


consistently appearing in the diet are snails and chi ronomids. Chironomids, especially, are preferred by pintails and are extremely abundant on emergence from shallow wetlands immediately after ice-out. The arrival of pintails on many migration and breeding habitats tends to coincide with this period of emergence, and pintails forage voraciously on chironomids in such newly thawed wetlands.

Pintails strip seeds from the culms of native vegetation before seeds drop in fall. Once seeds have dropped onto the substrates, pintails dabble for these foods in shallow water (4 to 6 inches). As water deepens, pintails forage by upending, but this mode of feeding is restricted to waters $<18$ inches deep. Pintails have a tendency to avoid areas that are flooded too deeply if shallow sites also are present.

\section{Habitat Management}

\section{Migration and Winter}

Pintails are noted for their use of large expanses of shallow, open habitats. These wetlands often provide an abundance of food and good visibility for avoidance of predators and other disturbances during the day. At night, habitats with greater, robust cover are often sought. Although they forage in openings in southern hardwoods, pintails generally do not use flooded sites in the forest interior. Similarly, they are less apt to use woody riparian corridors than are mallards or wood ducks.

Many well-managed wetlands have the potential to provide an abundant supply of high-energy and nutritionally complete foods for pintails when water depths are $<18$ inches and preferably $\varangle 6$ inches. Gradual flooding and draining of impoundments at appropriate times during spring and fall migration create conditions that allow optimal foraging opportunities over extended periods. When impoundments vary in depth by more than 18 inches, gradual flooding increases the potential for pintails to consume more available seeds. Waters $>18$ inches can still provide important roost sites and give security from predators. Newly developed wetland areas are more easily managed for pintails if levees and other water control structures are configured to provide the maximum area in optimal foraging depths of $\leq 18$ inches.

Table 2. Nutritional values ${ }^{\mathrm{a}}$ of some important foods consumed by northern pintails.

\begin{tabular}{|c|c|c|c|c|c|c|c|}
\hline \multirow[b]{2}{*}{ Plant foods } & \multicolumn{2}{|c|}{ Energy kcal/g } & \multicolumn{5}{|c|}{ Percent } \\
\hline & Gross & Metabolized & Fat & Fiber & Ash & $\mathrm{NFE}^{\mathrm{b}}$ & Protein \\
\hline Nodding smartweed & 4.6 & - & 2.7 & 22.0 & 7.5 & - & 9.7 \\
\hline Big-seeded smartweed & 4.3 & 1.1 & 2.6 & 19.1 & 3.8 & 67.3 & 10.6 \\
\hline Wild millet & 3.9 & - & 2.4 & 23.1 & 18.0 & 40.5 & 9.1 \\
\hline Walter's millet & 4.5 & 2.8 & 3.9 & 13.7 & 5.8 & 55.7 & 16.8 \\
\hline Sticktights & 5.0 & - & 13.2 & 20.9 & 8.9 & 27.5 & 23.1 \\
\hline Rice cutgrass & 3.9 & 3.0 & 2.0 & 10.6 & 9.3 & 57.8 & 12.0 \\
\hline Fall panicum & 4.0 & - & 6.1 & 16.8 & 16.1 & 50.1 & 12.0 \\
\hline Hairy crabgrass & 4.4 & - & 3.0 & 11.1 & 9.7 & 59.4 & 12.6 \\
\hline Redrooted sedge & 5.2 & - & - & - & - & - & - \\
\hline Curly dock & 4.3 & - & 1.2 & 20.4 & 6.9 & - & 10.4 \\
\hline Bulrush & 3.5 & 0.8 & 3.0 & 23.6 & 4.3 & 59.1 & 7.2 \\
\hline Pondweed & 3.9 & 0.4 & 2.1 & 20.6 & 15.0 & 50.6 & 14.0 \\
\hline Chufa seeds & - & - & 22.0 & 5.6 & 5.1 & 58.9 & 8.4 \\
\hline Chufa tubers & 4.3 & - & 10.6 & 7.3 & 3.1 & 57.1 & 7.0 \\
\hline Barley & - & 2.9 & 2.1 & 7.1 & 3.1 & - & 20.0 \\
\hline Rice & - & 2.3 & 9.3 & 11.4 & 9.7 & 73.5 & 10.8 \\
\hline Corn & 4.4 & 3.7 & 4.0 & 2.3 & 1.5 & 77.4 & 11.6 \\
\hline
\end{tabular}

${ }^{a}$ Values are averages cal culated from publ ished information. Because of wide variation in values for some seeds and inconsistency in sample sizes for each nutrient, the sum of values may not be $100 \%$.

${ }^{b} \mathrm{NFE}=$ Nitrogen-free extract (highly digestible carbohydrates) 
Because waste grains from agricultural production are of great importance to pintails, refuge or farm programs that make these grains available after harvest have special value for pintails in certain areas. Pintail use is increased by shallow flooding of any crop or by manipulating rice stubble by rolling or burning. Barley and rice usually are preferred over corn, although corn is consumed extensively in some locations such as the Sacramento-San J oaquin Delta of California. Maintaining ideal foraging conditions throughout winter and during spring migration provides required resources for molt, migration, and deposition of reserves for breeding. Stable water levels are undesirable, but gradual drawdowns have the potential to increase the vulnerability of invertebrate prey and to make seeds within mud substrates accessible. F urthermore, some good foraging sites should be protected from disturbance by hunters, bird watchers, aircraft, and boaters, as well as from management activities throughout fall and winter.

\section{Breeding}

The highest nesting densities occur in open habitats where vegetation is low and sparse. Common plants in these locations include prairie grasses, whitetop, nettle, spike rush, rushes, and buckbrush. Pintails nest in agricultural lands more frequently than other dabblers and readily use pastures, stubble fields, roadsides, hayfields, fallow fields, and the edges or margins around grain fields. In the boreal forest, nesting is concentrated on more open areas with sedge or grass meadows.

Establishment of tall, dense cover is a common practice to provide nesting sites for some dabblers. This practice is less valuable for pintails because they prefer sparser cover for nesting. Grazing programs that leave good residue ground cover but remove robust growth can enhance nesting cover for pintails. Well-conceived farm programs that protect habitats and ephemeral wetlands are especially important for breeding pintails. Because pintails regularly nest in agricultural lands, programs that provide benefits to farmers for delaying haying or for protecting nesting cover surrounding wetlands have the greatest potential to increase pintail recruitment.

\section{Summary}

Pintails offer a great challenge to waterfowl managers because they associate with many habitats that are used intensively by agricultural interests. Their preference for open areas and small, shallow wetlands in areas with little rainfall and recurring droughts puts a large part of their breeding area in jeopardy regarding consistent conditions. Developing farm programs compatible with pintail life history requirements offers the greatest opportunities for habitat enhancement, and therefore population recoveries by pintails on the prairies. Northern boreal and tundra habitats must be protected from loss or degradation.

Adequate migration and wintering habitats must be protected, restored, and enhanced. This will require continued acquisitions or other means of protection of key habitats and more effective management of public and private wetlands. One of the greatest opportunities to enhance wintering and migration habitats is to identify scenarios that will benefit rice culture and simultaneously provide needed resources for pintails. This adaptable, highly mobile species has a history of responding rapidly to good habitat conditions across the continent. By providing these habitats to pintails, we can assure their survival and abundance in the future.

\section{Suggested Reading}

Bellrose, F. C., editor. 1980. Ducks, geese, and swans of North America. 3rd ed. Stackpole Books, Harrisburg, Penn. 540 pp.

Fredrickson, L. H., and F. A. Reid. 1988. Nutritional values of waterfowl foods. U.S. Fish Wildl. Serv., Fish Wildl. L eafl. 13.1.1. 6 pp.

Krapu, G. L., and G. A. Swanson. 1975. Some nutritional aspects of reproduction in prairie nesting pintails. J . Wildl. Manage. 39:156-162.

Miller, M. R. 1986. Northern pintail body condition during wet and dry winters in the Sacramento Valley, California. J. Wildl. Manage. 50:189-198.

Raveling, D. G., and M. E. Heitmeyer. 1989. Relationships of population size and recruitment of pintails to habitat conditions and harvest. J. Wildl. Manage. 53:1088-1103. 


\section{Appendix. Common and Scientific Names of Plants and Animals Named in Text.}

\section{Plants}

Toothcup or Ammania

Sticktights

Sedges

Redroot flatsedge

Chufa flatsedge

Hairy crabgrass

J apanese millet

Walter's millet or wild millet

Spike rush

Swamp timothy

Barley

Rush

Rice cutgrass

Sprangletop

Rice (cultivated)

Panicum or panic grass

Nodding smartweed or smartweed

Big-seeded smartweed or Pennsylvania smartweed

Pondweeds

Curly dock

Bulrush

Whitetop

Buckbrush or snowberry

Nettle

Corn or Indian corn
Ammania coccinea

Bidens sp.

Carex spp.

Cyperus erythrorhizos

Cyperus esculentus

Digitaria sanguinal is

Echinochloa crusgalli

E chinochloa wal teri

Eleocharis sp.

Heleochl oa schoenoi des

Hordeum vulgare

$\mathrm{J}$ uncus sp.

Leersia oryzoides

Leptochl oa spp.

Oryza sativa

Panicum spp.

Polygonum Iapathi fol ium

Polygonum pensylvanicum

Potamogeton spp.

Rumex spp.

Scirpus sp.

Scol ochloa festucacea

Symphoricarpos spp.

Urtica spp.

Zea mays

Aix sponsa

Anas acuta

Anas platyrhynchos

\section{Invertebrates (Families)}

Chironomids

Earthworms

Chironomidae

Lumbrididae

\section{UNITED STATES DEPARTMENT OF THE INTERIOR \\ FISH AND WILDLIFE SERVICE \\ Fish and Wildlife Leaflet 13 \\ Washington, D.C. • 1991}

